\title{
Tip of the clade on the top of the World-the first fossil Lophopidae (Hemiptera: Fulgoromorpha) from the Palaeocene of Tibet
}

\author{
Jacek Szwedo $^{1} \cdot$ Adam Stroiński $^{2} \cdot{\text { Qibin } \text { Lin }^{3}}^{3}$
}

Received: 22 January 2015 /Revised: 12 April 2015 / Accepted: 14 April 2015 / Published online: 28 April 2015

(C) The Author(s) 2015. This article is published with open access at Springerlink.com

\begin{abstract}
Lophopidae is a family of planthoppers (Hemiptera: Fulgoromorpha) present today in tropical and subtropical zones of the Old World. The most recent taxonomic studies and phylogeny of these insects do not include the extinct representatives. Therefore, each new discovery of a fossil lophopid is of high interest, giving new insights to their evolutionary history and enabling to test the proposed relationships. The recent findings of extinct Lophopidae in Europe, in various Palaeogene deposits, put in doubts their proposed evolutionary and biogeographic scenario. The new fossil from the Palaeocene of Northern Tibet is related to one of the Lophopidae clades, $\mathrm{Apia}^{+}$group, believed to be the most advanced one, and recently distributed in the recent Sundaland-New Guinea-Queensland area. A new genus and species Gesaris gnapo gen. et sp. n. provide information on early lophopids diversity and relationships and demonstrates the necessity for a revision of the existing hypotheses for the
\end{abstract}

Communicated by: Sven Thatje

Electronic supplementary material The online version of this article (doi:10.1007/s00114-015-1277-4) contains supplementary material, which is available to authorized users.

Jacek Szwedo

jacek.szwedo@biol.ug.edu.pl

Adam Stroiński

adam@miiz.waw.pl

1 Department of Zoology and Parasitology, University of Gdańsk, 59, Wita Stwosza St., PL80-308 Gdańsk, Poland

2 Museum and Institute of Zoology, Polish Academy of Sciences, 64, Wilcza Street, PL00-679 Warszawa, Poland

3 State Key Laboratory of Palaeobiology and Stratigraphy, Nanjing Institute of Geology and Palaeontology, Chinese Academy of Sciences, Nanjing 210008, People's Republic of China initial diversification and distributional pattern of the Lophopidae.

Keywords Insecta $\cdot$ Lophopidae $\cdot$ Palaeocene $\cdot$ Tibet $\cdot$ Phylogeny $\cdot$ Biogeography $\cdot$ Taxonomy

\section{Introduction}

The planthopper family Lophopidae Stål, 1866 is one of the smallest within Fulgoroidea, with 43 genera and over 140 species recognized, both recent and extinct (Bourgoin 2015; Szwedo 2011; Stroiński and Szwedo 2012). This tropical Old World family (except Carriona Muir, 1931 from Peru, Ecuador and Panama) is the first to have a modern generic level phylogenetic analysis, biogeographic scenarios proposed and host plants relationships discussed (Soulier-Perkins 1998, 2000, 2001; Soulier-Perkins et al. 2007, 2013; Szwedo and Soulier-Perkins 2010). The members of the family could be identified by unique combination of characters of head, legs, and tegmina (Soulier-Perkins 1998; Soulier-Perkins et al. 2013). There are a few known fossils ascribed to Lophopidae (see Supplementary Material for a full list and Fig. 2) known since Palaeocene to late Eocene.

\section{Material and methods}

The specimen was examined using dissecting stereoscopic microscope Nikon 1500 and illustrated with the aid of the drawing tube. Photographs were taken using Nikon Digital camera DXM and Zeiss SteREO Discovery.V20 system. The venation nomenclature follows Bourgoin et al. (2015). The generic groups are marked according to the convention proposed by Amorim (1982), i.e., the name given to a 
monophyletic group is the name of the more basal taxon in this, followed by the sign ${ }^{+}$

\section{Systematic paleontology}

\section{Family Lophopidae Stål, 1866}

Gesaris gen. n.

Type species Gesaris gnapo sp. n. by monotypy and present designation.

Diagnosis Pattern of venation close to the recent genus Maana Soulier-Perkins 1998. Costal area narrow at base without transverse veinlets, apical portion distinctly widened with a few veinlets (similar pattern in Maana); three rows of veinlets - nodal, subapical, and apical one present (as in Maana and other genera of the Apia ${ }^{+}$group); it differs from Maana and other genera of Apia ${ }^{+}$group by the sequence of forking of main stems- $\mathrm{M} \rightarrow \mathrm{ScP}+\mathrm{R}=\mathrm{CuA}$ (model $\mathrm{ScP}+\mathrm{R} \rightarrow \mathrm{M} \rightarrow$ $\mathrm{CuA}$ in the other genera of the Apia ${ }^{+}$group); branches $\mathrm{M}_{3+4}$ and $\mathrm{CuA}_{1}$ without common portion (branches $\mathrm{M}_{3+4}$ and $\mathrm{CuA}_{1}$ with a short common portion in Maana and other members of the Apia ${ }^{+}$group present).

Etymology Gesaris - name of the warrior king from the Tibetan, Chinese, and Mongolian mythology. Gender: masculine, third declension.

Composition Only type species Gesaris gnapo sp. n.

Description Tegmen narrow, about 3.5 times as long as wide, veins on membrane strongly elevated, carinate, with three rows of veinlets: nodal, subapical, and apical ones. Costal margin almost straight, costal area very narrow, parallel to costal margin, distinctly widened in the apical portion, forming 'stigmal area' (near nodal line); basal portion of costal area without veinlets, apical, widened portion ('stigmal area') with five oblique veinlets. Stems $\mathrm{ScP}+\mathrm{R}, \mathrm{M}$, and $\mathrm{CuA}$ leaving basal cell separately. Stem ScP $+\mathrm{R}$ forked apicad of stem $\mathrm{M}$ forking, at same level as stem $\mathrm{CuA}$ forking. Branch $\mathrm{ScP}+\mathrm{RA}$ forked slightly apicad of nodal line, with three terminals reaching margin. Branch RP forked apicad of nodal line, then forked subsequently at level of subapical and apical lines, reaching margin with four terminals. Stem $M$ forked at basal $1 / 3$ of tegmen length, distinctly basad of stems $\mathrm{ScP}+\mathrm{R}$ and $\mathrm{CuA}$ forkings. Stem $M$ forked basad of stems $\mathrm{ScP}+\mathrm{R}$ and $\mathrm{CuA}$ forkings. Branch $\mathrm{M}_{1+2}$ forked at level of nodal line, branch $\mathrm{M}_{3+4}$ forked distinctly basad of nodal line, branch $\mathrm{M}_{4}$ forked at nodal line. Stem $\mathrm{CuA}$ forked at same level as stem $\mathrm{ScP}+\mathrm{R}$ forking. Nodal line composed of veinlets: pccp-scpra (between $\mathrm{Pc}+\mathrm{CP}$ and $\mathrm{ScP}+\mathrm{R}), 1 \mathrm{ir}, 1 \mathrm{r}-\mathrm{m}$, and two veinlets $1 \mathrm{im}$. Subapical line present was composed of veinlets $2 \mathrm{ir}, 2 \mathrm{r}-\mathrm{m}$, and $2 \mathrm{im}$. Apical line present was composed of veinlets $3 i r, 3 r-m$, and $3 \mathrm{im}$.

Cell C1 narrower than postcostal cell, closed apically with nodal line veinlet 1ir. Cell C3 longer and wider than cell $\mathrm{C} 1$, closed with nodal veinlet $1 \mathrm{im}$. Cell C3a present basad of nodal line. Cell C5 narrower than cells $\mathrm{C} 1$ and $\mathrm{C} 5$, elongate, lancetshaped.

Postnodal cells about as long as apical cells, subapical cells shorter than apical cells.

Remarks Based on the venational patterns, Gesaris gen. n. belongs to the Apia ${ }^{+}$clade as delimited by Soulier-Perkins (2000, 2001). This generic group comprises nine extant genera: Acarna Stål, 1863; Apia Distant, 1909; Jugoda Melichar, 1915; Kasserota Distant, 1906; Maana Soulier-Perkins 1998; Magia Distant, 1907; Megacarna Baker, 1925; Onycta Fennah, 1955; and Zophiuma Fennah, 1955. Within this group, the subunit encircling Maana, Kasserota, Acarna, Magia, and Onycta form a separate subclade. This subclade could be delimited by the elongate tegmina with sparse but regular lines of veinlets on membrane: nodal, subapical, and apical ones; very narrow costal area, with veins $\mathrm{CA}$ and $\mathrm{Pc}+$ $\mathrm{CP}$ very close each other in basal portion, always without veinlets in between and widened in apical part, with veinlets in 'stigmal area'.

Gesaris gnapo sp. n.

(Fig. $1 \mathrm{a}-\mathrm{d}$ )

Diagnosis Tegmen hyperpterous in RP and $\mathrm{M}$ (sensu Bourgoin et al. 2015). Stem $\mathrm{ScP}+\mathrm{RA}$ reaching margin with three terminals: $\mathrm{ScPRA}_{1}, \mathrm{RA}_{2}$, and $\mathrm{RA}_{3}$; stem RP forking pectinate, reaching margin with four terminals. Stem $M$ reaching margin with eight terminals. Cell C3a $0.35 \times$ as long as cell C3.

Etymology Specific epithet is derived from the Tibetan word 'gna' po' meaning primeval, ancient.

Holotype Specimen No. NIGP 135805. Imprint of tegmen with clavus missing and postclaval margin partly destroyed. Deposited in the collection of the Nanjing Institute of Geology and Palaeontology, Chinese Academy of Sciences, Nanjing, China.

Type locality, horizon, and age Gangni Village, Anduo County, Dazhuoma area of the Qiangtang Basin in northern Tibet; Niubao Formation; Palaeocene. 

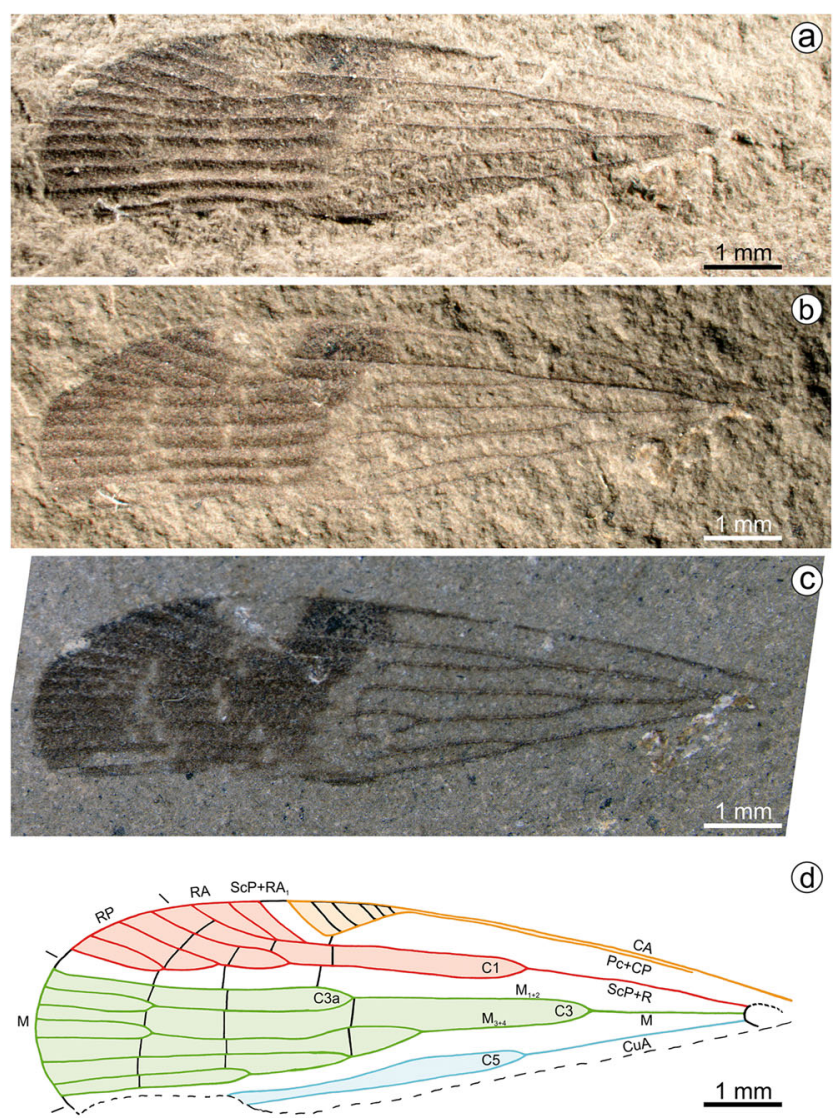

(d)

Fig. 1 Gesaris gnapo gen. et sp. n. a-c Photographs of the specimen under different light conditions. a, b Dry specimen under light from sides, c specimen under alcohol. d Reconstruction of tegmen venation

Description As for the genus. Length of tegmen $9.6 \mathrm{~mm}$, width $2.72 \mathrm{~mm}$. Cell C1 $2.48 \mathrm{~mm}$ long, cell C3 $3.32 \mathrm{~mm}$ long, cell C3a $1.16 \mathrm{~mm}$ long.

\section{Discussion}

The ancestor of the family Lophopidae was postulated as feeding on Arecaceae (Fig. 2), with two later changes to Poaceae and Musaceae (Soulier-Perkins et al. 2007). Three scenarios were made to explain the paradoxical biogeographic distribution of the Lophopidae based on different geological events and times (Soulier-Perkins 2000). After a new assessment of the existing data on fossil and recent Lophopidae and their postulated host plants, any of them match to the observed facts. The oldest fossil species of Lophopidae are now from Tibet (Gesaris gnapo gen. sp. n.--Apia ${ }^{+}$group) and Europe (Cintux menatensis Stroiński et Szwedo, 2012-Sarebasa ${ }^{+}$ group). Then, it could be assumed that Lophopidae has separated in Late Cretaceous, benefited from exploitation of the new habitats and host plants expansion due to Mid-Cretaceous re-organisation of biosphere (Szwedo and Soulier-Perkins 2010; Stroiński and Szwedo 2012). It seems probable that this

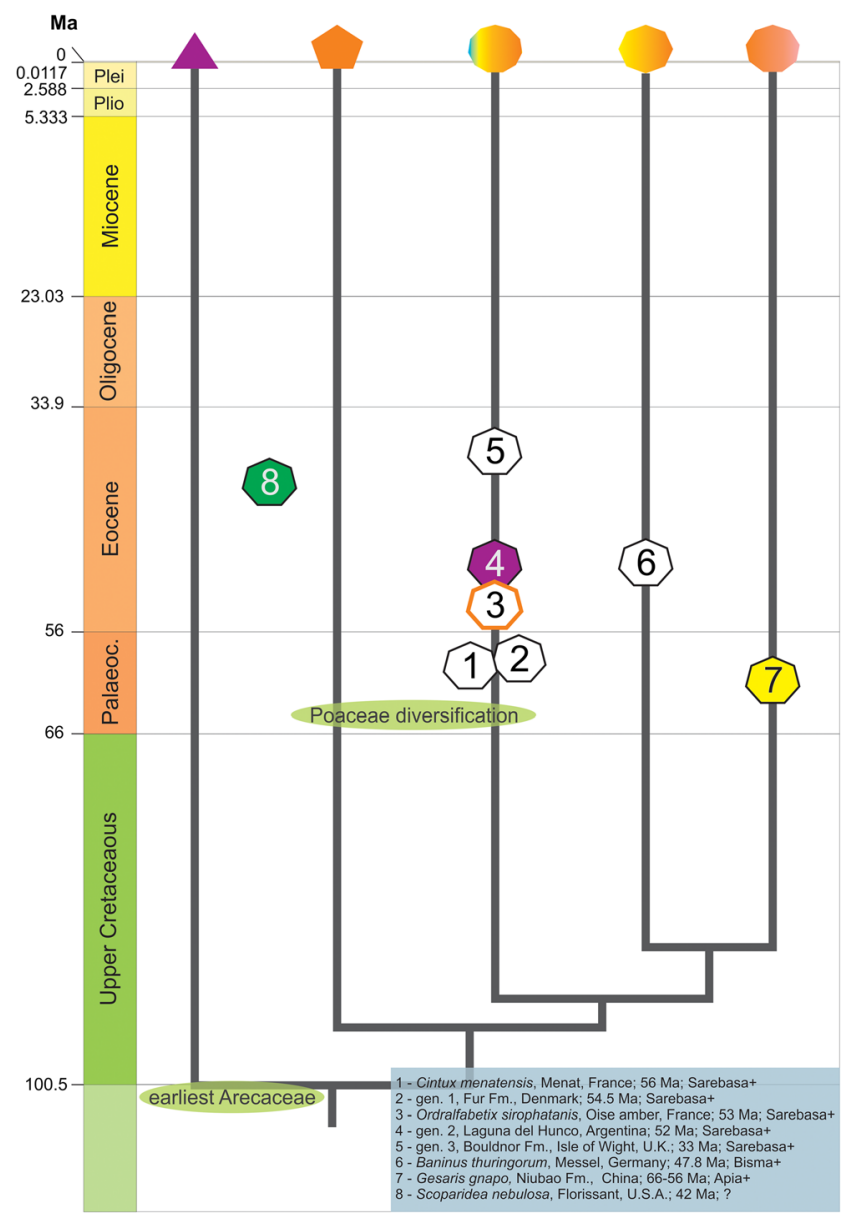

Fig. 2 Time and space distribution of fossil Lophopidae on the phylogenetic tree of lineages (generic groups) as proposed by SoulierPerkins $(2000,2001)$

separation took place somewhere in the ancestral area of Arecaceae and that Lophopidae committed a rather rapid diversification and spreading coincident with them. The ecological shift of Sarebasa ${ }^{+}$clade to Poaceae was postulated to take place in South-East Asia (Soulier-Perkins et al. 2007). This shift could be related to Poaceae massive diversification end expansion in the Palaeogene (Jones et al. 2014; Magallón et al. 2015). Only a sole species of monotypic genus-Megacarna albosparsa (Melichar, 1913) shifted to Musaceae. SoulierPerkins (2000) postulated that ancestors of the $\mathrm{Bisma}^{+}$group (to which the $\mathrm{Apia}^{+}$clade comprises) originated in the West Pacific islands arc. Eleven of the concerned genera are found in terranes originating from this arc. However, the oldest fossil ascribed to the $\mathrm{Bisma}^{+}$group-Baninus thuringiorum Szwedo et Wappler, 2006-comes from the Middle Eocene Messel Maar (Szwedo and Wappler 2006). Finding of the representative of the $\mathrm{Apia}^{+}$group, the group believed to be the most advanced among the Lophopidae in the Palaeocene of Qiangtang Basin pushes back the time of separation of at least of this group of genera, but also questions the postulated area of origination. Ancestors of the modern $\mathrm{Apia}^{+}$group 
could originate earlier than formerly supposed (Soulier-Perkins 2000). The presence of extinct members of the Bisma ${ }^{+}$ group in Europe (Szwedo and Wappler 2006) could support this statement. The early diversification and westward migrations of ancient Lophopidae probably took place in the early Palaeocene, due to suitable palaeogeographic and climatic conditions (Martin et al. 2013). It could be assumed that the 'invasion' of lophopids to the Indian subcontinent resulted from docking of it to mainland Asia. The palaeogeographic situation of the area is very complicated, a number of competing models for the Cretaceous evolution of the Tethys ocean between India and Eurasia were proposed, and these need to be understood both in the context of deformation in SE Asia, as well as in the Himalayas (Hall 2012). Also climatic changes - the Eocene Thermal Maximum (ETM2) and the subsequent Early Eocene Climatic Optimum (Zachos et al. 2008) influenced this expansion. Following climatic and biotic events of late Palaeogene and Neogene (Shukla et al. 2013) left the isolated genus Bisma Distant, 1907 in Ceylon as a relic of wider distribution in the past. Ancestors of the recent genera of the Apia ${ }^{+}$group could reach New Guinea at about 25-20 Mya, when the East Philippines-Jalmaher-South Caroline Arc collided with the Australian Plate at the north New Guinea margin (Hall et al. 2011). Ancestors of recent Magia species probably 'invaded' Australia later, during PliocenePleistocene (Soulier-Perkins 2000). The recent genera placed in the $\mathrm{Apia}^{+}$group seem to be relatively young descendants of the much older ancestral forms, present in the Palaeocene. Such evolutionary history of the $\mathrm{Apia}^{+}$group seems to be reflected in its recent distribution (Soulier-Perkins 2000) and trophic relationships of the recent taxa (Soulier-Perkins 2007).

\section{Conclusion}

It could be concluded that discovery of fossil Lophopidae in Palaeocene deposits of Tibet gives a new clue to evolutionary and distributional patterns of the Lophopidae. The recent distribution of this group and its subunits seems to be result of millions of years of dispersal and extinction events, as well as vicariance events in some areas, influenced by changes of the availability of host plants, host-plants shifting and biotic and climatic changes at global and local scale. Scarce data on fossil insects from the most crucial period of Palaeogene faunistic turnover in Asia after the collision with Indian plate are available (Lin et al. 2010; Szwedo et al. 2013). Fossils from Tibet can bring new insights not only to evolution of groups, but also into paleoevents of biotic reorganization and formation of modern fauna of Asia.

Acknowledgments This paper partly results from the scientific exchange project of Chinese Academy of Sciences and Polish Academy of Sciences "Palaeobiodiversity of Fulgoromorpha and Cicadomorpha (Insecta: Hemiptera) of Daohugou Biota" awarded to JS.

Open Access This article is distributed under the terms of the Creative Commons Attribution 4.0 International License (http:// creativecommons.org/licenses/by/4.0/), which permits unrestricted use, distribution, and reproduction in any medium, provided you give appropriate credit to the original author(s) and the source, provide a link to the Creative Commons license, and indicate if changes were made.

\section{References}

Amorim DS (1982) Classificação por seqüenciação: uma proposta para a denominação dos ramos retardados. Rev Bras Zool 1:1-9

Bourgoin T (2015) FLOW (Fulgoromorpha Lists On the Web). Version 8 , updated 02-03-2015 http://hemiptera-databases.org/flow/?db= flow\&page $=$ home\&lang $=$ en

Bourgoin T, Wang R-R, Asche M, Hoch H, Soulier-Perkins A, Stroiński A, Yap S, Szwedo J (2015) From micropterism to hyperpterism: recognition strategy and standardized homology-driven terminology of the forewing venation patterns of planthoppers (Hemiptera: Fulgoromorpha). Zoomorphology 34:63-77

Hall R (2012) Late Jurassic-Cenozoic reconstructions of the Indonesian region and the Indian Ocean. Tectonophysics 570-571:1-41

Hall R, Cottam MA, Wilson MEJ (2011) The SE Asian Gateway: History and Tectonics of the Australia-Asia Collision. Geol Soc, London, Spec Publ 355, 381 pp

Jones SS, Burke SV, Duvall MR (2014) Phylogeneomics, molecular evolution and estimated ages of lineages from deep phylogeny of Poaceae. Plant Syst Evol 300:1421-1436

Lin QB, Szwedo J, Huang DY, Stroiński A (2010) Weiwoboidae fam. nov. of 'higher' Fulgoroidea (Hemiptera: Fulgoromorpha) from the Eocene deposits of Yunnan, China. Acta Geol Sin-Engl Ed 84:751-755

Magallón S, Gómez-Acevedo S, Sánchez-Reyes LL, HernándezHernández T (2015) A metacalibrated time-tree documents the early rise of flowering plant phylogenetic diversity. New Phytol. doi:10. 1111/nph.13264

Martin P, Grimes S, Manners H, Hart M (2013) A critical evaluation of the Paleocene-Eocene Thermal Maximum: an example of things to come? Plymouth Stud Scientist 6:386-397

Shukla A, Mehrotra RC, Guleria JS (2013) Emergence and extinction of Dipterocarpaceae in western India with reference to climate change: Fossil wood evidences. J Earth Syst Sci 122:1373-1386

Soulier-Perkins A (1998) The Lophopidae (Hemiptera: Fulgoromorpha): description of three new genera and key to the genera of the family. Eur J Entomol 95:599-618

Soulier-Perkins A (2000) A phylogenetic and geotectonic scenario to explain the biogeography of the Lophopidae. Palaeogeogr Palaeoclimat Palaeoecol 160:239-254

Soulier-Perkins A (2001) The phylogeny of the Lophopidae and the impact of sexual selection and coevolutionary sexual conflict. Cladistics 17:56-78

Soulier-Perkins A, Ouvrard D, Attié M, Bourgoin T (2007) Evolutionary patterns in biogeography and host plant association: 'taxonomic conservatism' in Lophopidae (Hemiptera, Fulgoromorpha). Syst Entomol 32:305-311

Soulier-Perkins A, Stroiński A, Szwedo J (2013) Where will the lophopid's fossils be placed with the morphology-based phylogeny of the family (Hemiptera: Fulgoromorpha: Lophopidae)? Program and Abstracts. $14^{\text {th }}$ International Auchenorrhyncha Congress and $8^{\text {th }}$ International Workshop on Leafhoppers and Planthoppers of 
Economic Importance, Northwestern A\&F University, Yangling, China, 8-12 July, 2013:70-71

Stroiński A, Szwedo J (2012) The oldest known Lophopidae planthopper (Hemiptera: Fulgoromorpha) from the European Paleocene. Geobios 45:413-420

Szwedo J (2011) Ordralfabetix sirophatanis gen. et sp. n.- the first Lophopidae from the Lowermost Eocene Oise amber, Paris Basin, France (Hemiptera: Fulgoromorpha). Zootaxa 2822:52-60

Szwedo J, Soulier-Perkins A (2010) Hopping in Palaeo-World-new proposal for migration routes of Lophopidae (Hemiptera: Fulgoromorpha). $13^{\text {th }}$ International Auchenorrhyncha Congress, $7^{\text {th }}$ International Workshop on Leafhoppers and Planthoppers of
Economic Significance, $28^{\text {th }}$ of June - $2^{\text {nd }}$ of July 2010, Vaison-laRomaine, France:28-29

Szwedo J, Wappler T (2006) New planthoppers (Insecta: Hemiptera: Fulgoromorpha) from the Middle Eocene Messel Maar. Ann Zool 56:555-566

Szwedo J, Stroiński A, Lin QB (2013) Discovery of Flatidae planthopper (Hemiptera: Fulgoromorpha) in the Palaeocene of Northern Tibet and its taxonomic and biogeographic significance. Geodiversitas 21:291-298

Zachos JC, Dickens GR, Zeebe RE (2008) An early Cenozoic perspective on greenhouse warming and carbon-cycle dynamics. Nature 451: $279-283$ 